\title{
Perkembangan Islam di Indonesia Era Reiormasi
}

\author{
M. Sauki \\ Sekolah Tinggi Agama Islam Negeri (STAIN) Sorong Papua Barat \\ saukiali07@gmail.com
}

Abstract: Islam in Indonesia has existed since in the $7^{\text {th }}$ and became more widespread in the $13^{\text {th }}$. The success of Islam spread in Indonesia including the most dynamic with the method of cultural and political da'wah. Since the era of independence, Islam has grown rapidly. This paper aims to examine the existence of Islam in Indonesia today, with a review before the reform era and after reform. The Islamic movement can be said to be very influential on Indonesia's independence. This is evident from the role of Islamic organizations and parties. Despite its dominant influence, Islam did not become the official ideology of the Indonesian state after independence, as in the events of the Jakarta Charter, Islamic leaders preferred Pancasila as the principle of a pluralistic state. Uniquely, despite the predominantly Muslim population, Islam is not formally exposed in the system of government. After the Reform Era, many new Islamic parties and organizations were established. In Islamic conception, in general, reform is understood as ishlāh, which is in the ushul fiqh rules "keeping something good from the old and taking on the better of the new." Therefore, Islamic leaders are required to observe the global situation and its influence on Indonesia. Post reform also emerged a variety of radical Islamic organizations, terrorism, and movements that demand the implementation of Islamic law in all forms of order 
carried by certain Islamic movements, such as Hizbut Tahrir Indonesia and others. These problems make Islam a very sensitive issue: claims against Muslim representation, blasphemy, exclusivity and confusion between religion and politics without criticism. Such conditions precisely complicate the development of Islam in Indonesia that should consolidate and strengthen the interests of Islam. Furthermore, this condition is exacerbated also by the emergence of politicization and commercialization of Islamic identity in the context of da'wah, education and public media.

Keywords: The Existence of Islam in Indonesia, Islamic Movement, Islamic Identity, Muslim Representation, Islamic Ideology, and Pancasila.

\section{Pendahuluan}

Islam adalah agama rahmatan lil 'álamìn, yang menjadi rahmat bagi seluruh alam, ajarannya bersifat menyeluruh dan terpadu, ia mengatur seluruh aspek kehidupan manusia, baik dalam urusan-urusan keduniaan, maupun hal-hal yang menyangkut keakhiratan. Ajaran yang dibawakannya senantiasa sesuai dengan perkembangan zaman, dan berlaku untuk sepanjang masa menurut tuntutan situasi dan kondisi, atau dalam istilah yang sering disebutkan adalah al-Islām shālih li kulli zamān wa makān. Tercatat dalam sejarah bahwa Islam masuk ke Indonesia pada abad $1 \mathrm{H}$ atau abad ke-7 $\mathrm{M}^{1}$ dan semakin meluas pada abad

1 Sidi Ibrahim Boechari, Pengaruh Timbal Balik antara Pendidikan Islam dan Pergerakan Nasional di Minangkabau (Jakarta: Gunung Tiga, 1981), 32. Lihat juga Hasbullah, Sejarah Pendidikan Islam di Indonesia, Cet. IV (Jakarta: PT. Raja Grafindo Persada, 2001), 17. Dalam seminar masuknya agama Islam di Indonesia yang diselenggarakan di Medan pada 1963 menyimpulkan sebagai berikut: (1) Islam pertama kali datang di Indonesia pada abad ke-7 M (abad ke-1 H), dibawa oleh pedagang dan mubaligh dari negeri Arab; (2) Daerah yang pertama dimasuki ialah pantai Barat Sumatera, yaitu di daerah Baros, tempat kelahiran ulama besar bernama Hamzah Fansuri. Adapun kerajaan Islam yang pertama ialah di Pase (Pasai); (3) Dalam proses pengislaman selanjutnya, orang-orang Islam bangsa Indonesia ikut aktif mengambil bagian yang berperan dan proses itu berjalan secara damai; (4) Kedatangan Islam di Indonesia ikut mence- 
ke-13 M. ${ }^{2}$ Keberhasilan Islam menembus dan mempengaruhi kehidupan masyarakat Indonesia, serta menjadikan dirinya sebagai agama utama bangsa ini, merupakan prestasi luar biasa. Hal ini terutama bila dilihat dari segi geografis, di mana jarak Indonesia dengan negara asal Islam, Jazirah Arab cukup jauh. Dengan demikian, kedatangan dan perkembangan Islam di Indonesia termasuk paling dinamis.

Keberhasilan Islam menyebar dan menyusup ke tengah-tengah masyarakat Indonesia pada awalnya, belum didukung dengan adanya semacam organisasi atau metode dakwah yang efektif seperti sekarang ini. Organisasi Islam pada waktu itu, mungkin baru merupakan perkumpulan beberapa orang yang melakukan keinginan bersama untuk menyebarkan ajaran Islam. Sampai kemudian pada tahun 1990-an, organisasi-organisasi Islam mulai bermunculan.

Memasuki era reformasi, atau bersamaan dengan turunnya Soeharto dari kursi kepresidenan, muncul organisasi-organisasi Islam radikal dan fundamental. Di satu sisi, munculnya organisasi radikal dan fundamental, manandakan bahwa Islam di Indonesia semakin berkembang. Namun di sisi lain, perkembangan itu disertai kemunduran oleh sebab nama Islam sering diidentikkan dengan terorisme. Para pelaku teror, dan peledakan di mana-mana adalah orang Islam sendiri. Di era reformasi pula, partapartai Islam banyak bermunculan, dan hal ini merupakan bukti bahwa Islam semakin berkembang di negara ini. Namun, hal itu bukan satusatunya barometer oleh sebab partai-partai Islam tersebut tidak begitu unggul ketimbang partai-partai lain tidak berafiliasi pada nama Islam. Justru yang menang mutlak pada Pemilu tahun 1999 adalah PDI-P yang

daskan rakyat dan membina karakter bangsa. Uraian lebih lanjut, lihat Zuhairini, et.al. Sejarah Pendidikan Islam, Cet. II (Jakarta: Proyek Prasarana dan Sarana Perguruan Tinggi Agama, Dirjen Pembinaan Kelembagaan Agama Islam, 1986), 133.

2 Sebenarnya, abad ke-13 M disebut-sebut pendapat terkuat sebagai awal mula masuknya Islam di Indonesia, jadi bukan abad ke-7. Uraian lebih lengkap, lihat misalnya, Ira M. Lapidus, A History of Islamic Societies (Sejarah Sosial Umat Islam), terj. Ghufran A. Mas'adi, Bagian I \& II, Cet. III (Jakarta: PT. Raja Grafindo Persada, 2003), 728; Ajid Thohir, Perkembangan Peradaban di Kawasan Dunia Islam (Jakarta: PT. Raja Grafindo Persada, 2004), 201-202. Bandingkan dengan Hasbullah, Sejarah Pendidikan Islam, 5-6. 
jelas-jelas bukan partai yang berafiliasi Islam. Berkenaan dengan itulah, sangat menarik bila eksistensi Islam di Indonesia dewasa ini, dicermati dalam dibahas secara mendalam.

\section{Sejarah Islam Pra-Reiormasi}

Kedatangan Islam ke Indonesia, pada awalnya melalui jalur perdagangan, dan penerimaannya memperlihatkan dua pola yang berbeda, yakni bottom up dan top down. ${ }^{3}$ Para pendakwah Islam, datang di negara ini dengan menggunakan kapal layar dan berlabu di bandar Perlak, bersama dengan pelaksana dakwah berjumlah 100 orang terdiri dari orang Arab, orang Persia, dan orang India yang dipimpin oleh nahkoda khalifah. ${ }^{4}$ Mereka ini menyebarkan agama dengan metode ceramah di kampung-kampung dan metode kawin-mawin dengan keluarga istana. ${ }^{5}$ Dengan pendekatan kepada raja, maka Islam berkembang dengan cepat sehingga dikenal Kerajaan Islam awal di Indonesia adalah Perlak, Samuri, dan Pasai.

Di samping itu, dikenal pula Kerajaan Siak I (Riau) memegang peranan sebagai kerajaan di Selat Malaka yang menguasai arus perdagangan antara India, China, dan Singasari (Majapahit). Penyebaran Islam diperkirakan pada abad ke-12 $\mathrm{M}$ ini dapat dilihat peninggalan kuburan Butaken (1128 M) yang bercorak Islam, yaitu kuburan Nizamuddin al-

3 Dengan pola bottom up, Islam diterima terlebih dahulu oleh masyarakat lapisan bawah, kemudian berkembang dan diterima oleh masyarakat lapisan atas atau elit penguasa kerajaan. Sedangkan pola top down, Islam diterima langsung oleh elit penguasa kerajaan, kemudian disosialisasikan dan berkembang ke masyarakat bawah. Lihat Ahmad M. Sewang, Islamisasi Kerajaan Gowa, Cet. II (Jakarta: Yayasan Obor Indonesia, 2005), 86-87.

4 Muhammad Syamsu AS, Ulama Pembawa Islam di Indonesia dan Sekitarnya (Jakarta: Lentera Basritama, 1999), 1.

5 Salah seorang dari mereka, Sayyid Ali dari suku Quraisy kawin dengan putri yaitu Makhdum Tansyuri, salah saorang adik dari Meurah Perlak bernama Syakir Nuwi. Dari perkawinan ini lahir Sayid Abd. Azis putra campuran Arab-Perlak yang kemudian setelah dewasa, dilantik menjadi raja di Kerajaan Islam Perlak yang pertama pada tahun 225 H. Ibid., 2. 
Kamil Loksomawe dari Dinasti Fatimiah, Mesir. ${ }^{6}$

Pada Kerajaan Siak ini, memiliki penyiar agama dari negeri Arab di antaranya Sayid Usman bin Syahabuddin, seorang ulama yang alim yang berdakwah di Riau, karena raja menyukai akhlak beliau, maka dikawinkan dengan Badaria putri Kerajaan Siak. Dari keturunannya menjadi pewaris Kesultanan di Riau, dan selanjutnya melaksanakan dakwah ke Kalimantan barat sambil mengajarkan ilmu agama kepada para penduduk. ${ }^{7}$

Dilihat dari dinamika tersebarnya agama Islam di Aceh (Sumatera) bisa dikatakan tidak menghadapi tantangan yang berarti, karena dengan pendekatan kekeluargaan dengan penyesuaian diri secara autoplastis dan alloplastis dapat mengislamkan para raja dan pemuka masyarakat sampai membentuk kerajaan Islam. Hal ini tidak berbeda dengan cara berdakwah para Wali Songo di Jawa, dengan metode dakwah kultural, saat itu sangat kental dengan tradisi Hindu dan Budha. Di samping itu, Wali Songo membangun masjid sebagai sarana pusat atau media penyiaran agama.

Sama halnya di Sumatera dan Pulau Jawa, para ulama penyiar agama dari Arab berdakwah ke Kalimantan dan mendekati para raja untuk memeluk Islam dan menjadikan kerajaan Islam yang dipimpinnya. Di antaranya adalah kerajaan Tanjuppuara, Kerajaan Sambas. Di Kalimantan Barat dikenal Kerajaan Pontianak. Demikian pula di Kalimantan Selatan dan Timur, Islam masuk ke wilayah ini sejak zaman Raja Ali, Raja Mahkota (1526-1600 M). ${ }^{8}$

Di samping itu, di Sulawesi Selatan dikenal Kerajaan Gowa, kerajaan terbesar sesudah Kerajaan Sriwijaya dan Kerajaan Majapahit. Agama Islam masuk pada masa Raja Gowa IX, sekitar tahun 1583. Sultan Babullah datang ke Kerajaan Gowa dan menyebarkan Islam di Sulawesi

6 Suwardi Muhammad Samiun, et.al., Peranan Kerajaaan Siak dalam Sejarah Nasional Indonesia (Pekan Baru: Universitas Riau, 1970), 15.

7 Ibid., 19.

8 Ibid., 81-97. Syamsu AS, Ulama Pembawa Islam, 1. 
Selatan dan Tengah, bersamaan dengan pedagang-pedagang Muslim yang berasal dari Johor, Pasai di Sumatera.

Tercatat pula dalam sejarah bahwa daftar nama raja-raja Gowa yang pernah memerintah di Gowa sebanyak 36 orang. ${ }^{9}$ Dikenal nama I Manga'raungi Daeng Manrabbia Raja Gowa XIV yang diberi gelar Sultan Alauddin. Mangkubumi Kerajaan Gowa, I Malingkang Daeng Nyonri Karaeng Katangka (Raja Tallo) yang masuk Islam pada 22 September 1605 bergelar Sultan Abdullah al-Islam, dan atas inisiatif Sultan Alauddin bersama pengikut Muslim mendatangkan tiga orang ulama untuk kerajaan Gowa ${ }^{10}$ dalam upaya penyebaran Islam di wilayahnya.

Pada abad ke-16 masyarakat Sulawesi Selatan telah menganut agama Islam, masa Raja Gowa XV yaitu Sultan Malik al-Said (1639-1653), kecuali Tanah Toraja. Saat itu, Kerajaan Gowa menguasai hampir seluruh wilayah Nusantara bagian Timur, seperti Bima, Sumbawa, Timor, Sulawesi Tengah, Sulawesi Utara sampai ke Bali, Brunei dan Kutai. Sedang raja Gowa XVI adalah raja I Mallombasi Daeng Tawang Karaeng Bontomarannu yang dikenal dengan Sultan Hasanuddin-dengan keberaniannya menentang penjajahan Belanda yang akhirnya raja ini mendapat anugerah sebagai pahlawan nasional.

Dalam peta keagamaan, para ulama didukung oleh kerajaan menyebarkan agama ke seluruh nusantara. Mereka telah mewakafkan dirinya di nusantara ini sehingga dengan cepat agama Islam tersebar ke seluruh pelosok tanah air, sampai kita merebut kemerdekaan tahun 1945. Kondisi setelah merdeka dengan dipimpin oleh presiden yang nasionalis, ${ }^{11}$

9 Samiun, et.al., Peranan Kerajaaan Siak, 100. Mengenai daftar raja-raja Gowa, lihat, Sewang, Islamisasi Kerajaan Gowa, 183-184

${ }^{10}$ Ketiga ulama tersebut adalah adalah Khatib Tunggal Abdul Makmur (Datuk Ribandang) dan Khatib Sulaiman (Datuk Pattimang), serta Abdul Jawad Khatib Bungsu Maulana Datuk Tiro (Datuk Tiro). Ibid., 96-97. Lihat juga, Samiun, et.al., Peranan Kerajaaan Siak, 99.

${ }^{11}$ Gerakan sosial pertama yang mengkombinasikan antara kepentingan politik dengan motif keagamaan adalah Syarekat Islam (SI) yang dimulai sejak 11 November 1912 oleh H. Samanhudi. Kemudian meahirkan garis tegas antara ideologi politik Islam dengan idiologi non Islam. Lihat Eko Prasetyo, Membela Agama Tuhan: Potret Gerakan 
Soekarno, menimbulkan berbagai problem bagi umat Islam, kalaupun jauh sebelum merdeka sudah ada gerakan sosial keagamaan seperti organisasi Muhammadiyah, Nahdlatul Ulama, Persatuan Umat Islam, dan Perserikatan Umat Islam. Pada fase ini, penyebaran agama melalui lembaga organisasi keagamaan dan partai politik Islam, di samping juga secara individual kultural, penyebaran secara tradisional lewat ceramahceramah dan yang paling berpengaruh dalam gerakan Islam ialah Majelis Syuro Muslim Indonesia (Masyumi). ${ }^{12}$

Hampir semua organisasi Islam sebagai dasar partai dan selalu bercita-cita menegakkan ajaran Islam dalam masyarakat dan negara. Kaitan dengan ini, Muhammad Natsir (Pimpinan Masyumi) dalam hal konsep mengenai hubungan antara Islam dan negara tidak bergantung pada ada tidaknya Islam, tetapi pencapain terhadap kemakmuran dan keadilan rakyat. ${ }^{13}$ Pandangan yang moderat ini, mampu memberikan perspektif yang dingin ketika menghadapi Soekarno, seorang presiden dan pemimpin nasionalis yang memperdebatkan tentang sikap gerakan Islam terhadap Pancasila.

Beberapa pikiran dan dinamika gerakan Masyumi di antaranya, pandangannya atas negara kesatuan yang merupakan jawaban atas politik pecah belah Belanda, usulnya yang dikenal dengan nama "mosi integral" kemudian dipakai negara untuk menetapkan bentuk negara kesatuan. Muhammad Natsir juga melibatkan diri dalam Dewan Dakwah Islam (DDI) yang didirikan untuk melawan arus sekularisme dan Kristenisasi. Selanjutnya patut dicatat kebajikan Masyumi dalam soal perumusan dasar negara semula masalah ini bisa beres dengan pencutman tambahan katakata dengan "kewajiban menjalankan syariat Islam bagi pemeluknya”. Tetapi pada tanggal 18 Agustus 1945 kalimat yang populer dengan "Piagam Jakarta” dihapus. Muhammad Natsir barisan pendukung

Islam Pusaran Konflik Global, Cet. II (Yogyakarta: IPPI, 2003), 39.

12 Partai Masyumi ketika diadakan Muktamar Islam Indonesia di Yogyakarta tanggal 7 dan 8 November 1945 di dalamnya bergabung Muhammadiyah, Nahdlatul Ulama, Perserikatan Umat Islam, Persatuan Umat Islam.

${ }^{13}$ Ibid., 48. 
ideologis Islam berhadapan kembali dengan barisan nasionalis. ${ }^{14}$

Dengan berbagai problematika Masyumi sebagai partai politik Islam, dibubarkan dan beberapa tokohnya ditangkap ${ }^{15}$ dan diadakan penindasan, serta dipenjara sampai terjadi persaingan antara kekuataan PKI dengan militer, dan berakhir pada peristiwa G 30 September 1965. Masa ini dikenal dengan masa Orde Lama. Kemudian di masa Orde Baru, masjid merupakan corong dakwah sebagai media penyiaran agama dan acapkali menyuarakan protes pada beberapa langkah restruktualisasi Orde Baru. Dalam istilah Kuntowijoyo muncul gejala pada masa ini sebuah "Islamophobia" (fobia Islam) yang memandang Islam sebagai ancaman negara, maka pada tahun 1984, di Jakarta Utara (Tanjung Priok) terjadi konflik terbuka antara tentara dengan massa umat Islam yang menelan banyak korban, termasuk seorang aktivitis 66 dan juga pengusaha Muslim yang sukses yakni Amir Bibi.

Pada pemerintahan Orde Baru, "kecurigaan" yang mewarnai pola pikir umat, terutama antara Kristen dan Islam, misalnya tumbuh suburnya "Kristenisasi" dan pemanfaatan rumah sebagai tempat ibadah bagi umat Kristen, dan umat Islam selalu dicurigai karena sering memberikan masukan kepada pemerintah, misalnya tidak bisa mencegah pelanggaran antara lain tentang pelanggaran SKB Mendagri dan Menag No. 1 tahun 1969, SK Menteri Agama Nomor 70 \& 77 Tahun 1978 tentang Penyiaran Agama.

Di samping itu, perlu juga digarisbawahi bahwa dengan berbagai permasalahan yang terjadi, maka pemerintah (Orde Baru) mulai melakukan proses perubahan di tubuh militer dan juga Golkar. Berbagai kebijakan yang ditempuh Orde Baru untuk mendekatkan dengan kepentingan kalangan Muslim, seperti disahkannya UU Pendidikan Nasional 1989

\footnotetext{
${ }^{14}$ Pada pemerintahan Orde Lama melahirkan berbagai konflik dan pemberontakan seperti DI/TII, PRRI/Permesta RSMS dan G30S PKI.

${ }^{15}$ Di antara tokoh Islam yang ditangkap ialah Prawoto, Hamka, Kusuman Singodiarjo, Muhammad Room, M. Yunan Nasution, KH. M. Isa Anshari, dari tahun 19611967 tanpa melalui proses penyelidikan. Lihat Eko Prasetyo, Membela Agama Tuhan, 52.
} 
atau UU Pendidikan Agama (1989), Kompilasi Hukum Islam (1991), kebijakan baru Jilbab (1991), serta penutupan SDSB (1993). ${ }^{16}$

Sebelumnya itu, sudah ada kebijakan Orde Baru dalam mengakomodasi kepentingan politik Islam adalah pembentukan Bank Muamalat, serta didirikannya ICMI (1990). Namun, kebijakan ini mengkhawatirkan di kalangan sebagian umat, tentang pembentukan negara Islam, dan sasaran kritik adalah ketergantungan terhadap bantuan asing, dan jatuhnya korban serta hilangnya sejumlah mahasiswa semakin menyudutkan presiden Soeharto. Maka, pada 21 Mei 1997 Soeharto menyatakan pengunduran dirinya dari jabatan presiden.

\section{Dinamika Perkembangan Islam di Era Reiormasi}

Reformasi menurut kamus ilmiah populer berarti perubahan, perbaikan atau pembentukan baru. ${ }^{17}$ Artinya, perubahan yang dilakukan secara radikal untuk perbaikan sosial, ekonomi, budaya, politik atau agama di suatu masyarakat. Khusus dalam soal agama, yang dimaksud bukan perubahan atau merubah syariat, sebab syariat selamanya tidak akan berubah. Akan tetapi, yang diubah ialah pemikiran atau interpretasi terhadap syariat itu sendiri sehingga lebih cocok dengan apa yang dimaksud oleh al-Qur'an. Sesungguhnya term-term yang muncul di sekitar makna perubahan itu, seperti rekonstruksi (penyusunan kembali), reaktualisasi (penyadaran kembali), reinterpretasi (penafsiran kembali) dan berbagai term lainnya, juga berisi konsep-konsep perbaikan dan penataan kembali hal-hal yang dianggap sudah tidak relevan lagi

\footnotetext{
${ }^{16}$ Aminuddin, Kekuatan Islam dan Pergulatan Kekuasaan di Indonesia, Sebelum dan Sesudah Runtuhnya Soeharto (Yogyakarta: Pustaka Pelajar, 1999)

${ }^{17}$ Beberapa istilah mempunyai kedekatan makna meskipun secara terminologis tidak persis sama, seperti reformasi yang bermakna perubahan, pembentukan baru atau pembaharuan, senada dengan kata modernisasi yang juga berarti tajdid dalam bahasa Arab dan liberal yang berarti bebas berpendapat. Sementara istilah tradisional (bersifat turun-temurun) ekuivalen dengan kata konservatif (adat mempertahankan tradisi atau kebiasaan) atau fundamentalis (bermaksud mempertahankan ajaran pokok dari kepercayaan). Lihat, Pius A. Partanto \& M. Dahlan al-Barry, Kamus Ilmiah Populer (Surabaya: Arkola, 1994), 661.
} 
dengan perkembangan peradaban. Tuntutan perubahan muncul karena adanya kondisi sosial, ekonomi, budaya dan politik yang dianggap sudah tidak sesuai lagi dengan norma dan aturan-aturan hukum yang berlaku di masyarakat.

Bila pengertian reformasi dikaitkan istilah era yang berarti waktu dan masa yang sedang berlangsung, maka era refomasi yang dimaksud dalam konteks keindonesiaan adalah bermula sejak Habibi menggantikan Soeharto menjadi presiden. Masa ini sangat dikenal seluruh masyarakat yang dianggap menjadi penyelamat bagi kehidupan mereka, bahkan dianggap segala-segalanya. Ia muncul sebagai akibat dari keterpurukan ekonomi yang berdampak pada semakin beratnya beban hidup masyarakat. Di sisi lain, era reformasi boleh dikatakan sebagai hasil usaha bersama kelompok nasionalis (abangan) dan Islam (santri), dengan tema sentral memberantas korupsi, kolusi, dan nepotisme (KKN).

Reformasi dalam Islam identik dengan ishlāh, yakni memperbaiki dan menyempurnakan sesuatu yang belum sempurna, termasuk mengganti yang usang dan rusak. Hal ini sejalan dengan kaidah ushul fikih berikut. ${ }^{18}$

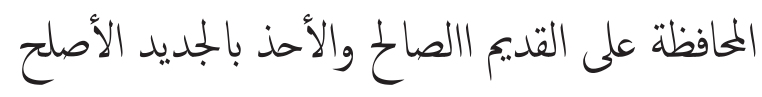

Karena itu, di Era Reformasi, para tokoh Islam dituntut untuk mencermati situasi global yang melahirkan beberapa revolusi karena dinamika era reformasi mengakibatkan bangsa Indonesia menghadapi problematika besar, yakni belum mampu keluar dari lilitan krisis ekonomi yang telah berlangsung demikian lama, dalam waktu yang bersamaan ancaman disintegrasi bangsa benar-benar merupakan sesuatu yang sangat nyata di pelupuk mata.

Sejak Pemilu 7 Juli 1999 partai Islam belum bisa menempatkan dirinya sebaga partai yang bisa diandalkan. Tanpa ada kebersamaan di antara umat tersebut, agaknya sulit untuk mengembangkan dan mem-

${ }^{18}$ Abd. Al-Hamid al-Hakim, al-Bayān fì Ilm al-Ushul (t.tt.: Maktabah Dahlān, 1978), 12. 
bumikan dakwah Islam di negara ini sebab mereka berkonsentrasi pada dinamika partai. Mula-mula partai politik umat Islam kalah bersaing dengan PDI perjuangan yang dianggap sekuler; PPP menjelma menjadi partai jinak apalagi ketika sebagian anggotanya bergabung di PBR; PKB yang mewakili NU juga terpecah; dan seterusnya. Terlepas dari perpolitikan umat Islam Indonesia di era reformasi yang masih belum menguntungkan, posisi kekuatan Islam untuk berkembang dalam segala aspek menarik untuk dikaji.

Selanjutnya, dan yang menjadi dinamika utama perkembangan Islam di era reformasi ini, situasi negara telah memunculkan gerakan sosial yang menuntut pemberlakuan syariat Islam pada semua bentuk tatanan. Dalam konteks ini, maka bermunculan organisasi seperti Forum Pembela Islam (FPI), Majelis Mujahidin Indonesia (MMI), Laskar Jihad, Forum Komunikasi Ahli Sunnah Waljamaah (FKSW), Hizbut Tahrir. ${ }^{19}$ Namun demikian, beberapa kalangan Muslim lainnya berpendapat bahwa Islam "tidak meletakkan suatu pola baku tentanng teori negara yang berdasar pada syariat Islam”. Terlepas dari perdebatan ini, yang jelas bahwa Islam semakin mengalami perkembangan dengan segala problematikanya, terutama dari aspek peta pemikiran, dan termasuk pengembangan nilainilai keagamaan.

Sehubungan dengan problematika era reformasi bagi bangsa Indonesia, pada kenyataannya sangat menyangkut eksistensi perkembangan Islam itu sendiri dan nasib masa depannya; apakah ajaran Islam akan semakin pudar bahkan tersingkir dari percaturan hidup bangsa, ataukah sebaliknya akan terjadi revivalisasi (kebangkitan) Islam atau lahirnya spirit baru kaum beragama di Indonesia. Dari asumsi awal bahwa kebangkitan Islam adalah fenomena global yang ada kaitannya dengan era reformasi. Hal ini disebabkan, dakwah Islam mengalami perkem-

\footnotetext{
${ }^{19}$ Pada akhir pemerintahan Orde Baru, telah ada Komite Solidaritas untuk Dunia Islam (KISDI) dan Persatuan Pekerja Muslim (PPHI), Ormas Majelis Mujahidin Indonesia (MMI) pimpinan Ustaz Abu Bakar Ba'asyir; Forum Pembela isam (FPI) pimpinan Habieb Riezieq; dan Laksar Jihad maupun Forum Komunikasi Ahlus Sunnah Waljamaah (FKSW) oleh Ajip Syafruddin dan Ikhwanul Muslimin, dimana ormas ini pada umumnya merupakan gerakan radikal.
} 
bangan sejak memasuki era reformasi.

Islam di Indonesia memasuki era reformasi mengalami perkembangan pesat dan dibuktikan dengan jumlah penduduk Muslim yang mencapai $+88 \%$. Penyebaran Islam ke seluruh wilayah tanah air dari kota-kota besar sampai ke daerah-daerah terpencil merupakan wujud dari kegiatan dakwah di era ini. Salah satu ciri dari agama dakwah adalah tertanamnya rasa moral yang tinggi di kalangan pemeluknya untuk menyebarkan dan memperkembangkan agamanya sebagai kewajiban luhur yang diyakini akan mendatangkan ganjaran pahala yang besar dari Tuhan, di samping memberi kepuasan batin bagi dirinya. Dalam Islam, kewajiban itu mendapatkan legitimasi dari al-Qur'an dan Hadis-hadis Nabi Saw berupa perintah menjadi $d \vec{a} i$ sesuai dengan kemampuan yang dimiliki oleh setiap Muslim.

Umat Islam di Indonesia tampaknya memiliki rasa dan tanggung jawab untuk mendakwahkan agama yang dipeluknya. Itulah sebabnya, kegiatan dakwah baik dalam arti verbal (bi lisān al-maqāl) maupun dalam arti praktis (bi lisān al-hāl) merupakan rutinitas umat. Dakwah yang sering diartikan sekadar ceramah dalam arti sempit, minimal sekali kegiatan terlihat dalam bentuk majelis-majelis taklim, khutbah-khutbah, kegiatan memperingati hari-hari besar Islam, pengajian-pengajian agama pada momen-momen tertentu, seperti kematian, perkawinan, aqiqah, hajatan haji, naik rumah baru dan semisalnya. Dalam skala yang lebih luas kegiatan dakwah secara intens dilakukan melalui lembaga-lembaga sosial keagamaan dari yang bertarap internasional, regional, nasional sampai kepada tingkat lokal. Lembaga-lembaga pendidikan yang berlabel Islam dari tingkat paling rendah sampai ke pendidikan tinggi juga aktif melakukan kegiatan-kegiatan dakwah.

Di kota-kota besar, kegiatan-kegiatan dakwah demikian marak karena hampir setiap komunitas atau kelompok Muslim aktif melaksanakan dakwah. Mulai dari lorong-lorong kumuh sampai ke hotel-hotel berbintang, dari kantor-kantor pemerintah sampai perusahaan-perusahaan kecil dan raksasa, pada umumnya mengadakan acara dakwah secara rutin. Bahkan kegiatan dakwah melalui media massa demikian 
gencarnya sehingga setiap pagi umat Islam di seluruh Indonesia dapat dengan bebas memilih saluran-saluran dakwah di radio dan televisi dan atau membacanya melalui media-media cetak. Di era teknologi informasi ini, internet merupakan media dakwah yang cukup menarik dan menjanjikan di masa depan.

Kegiatan dakwah yang begitu gencar dan marak di negeri ini, dari satu segi sangat menggembirakan karena bisa menjadi trade mark dari Islam Indonesia di era reformasi. Tetapi dari segi lain, banyak hal yang belum memberi kepuasan, misalnya dari aspek keberhasilan meningkatkan pemahaman penghayatan, pengamalan, kesadaran, dan wawasan keislaman di kalangan umat Islam itu sendiri.

Yang menjadi kendala, dan sekaligus salah satu penomena menarik di Indonesia era reformasi kini adalah munculnya $d \bar{a} \hat{i}$ - $d \bar{a} \mathfrak{i}$ atau mubalighmubaligh yang tidak memiliki latar belakang pendidikan agama secara formal, termasuk artis-artis yang menjadi $d \bar{a} ' i$ dadakan di bulan suci Ramadan. Tentu saja, plus minus dari kemunculan artis-artis sebagai $d \vec{a} i$, meskipun pada umumnya mereka tampil sebagai pembawa acara atau pemandu dari narasumber. Banyak kritik yang ditujukan kepada mereka, baik dari segi kostum maupun dari segi pengetahuan agama serta sikap dan perilaku mereka sehari-hari yang umumnya tidak sejalan dengan tampilan mereka sebagai pembawa acara dakwah, termasuk dalam hal ini pelawak-pelawak yang berakwah di media-media tertentu dan menjadikan agama sebagai bahan lawakan.

Ajaran-ajaran agama ditangkap dalam maknanya yang kaku dan tidak ada ruang untuk interpretasi yang berbeda. Mereka seringkali membuat klaim-klaim yang menempatnya diri dan fatwa-fatwanya sebagai yang paling benar sementara orang atau kelompok lain diposisikan sebagai pihak yang salah dan tidak perlu didengar, apalagi ditaati. Sikap seperti ini jelas sangat menghambat terjadinya proses pengembangan ajaran-ajaran Islam mengikuti dinamika era reformasi yang berubah terus-menerus.

Di sisi lain, munculnya kelompok-kelompok "sempalan" yang begitu semarak di era reformasi merupakan problema tersendiri karena dinamika dari kelompok tersebut begitu tinggi dalam mengembangkan ajaran- 
ajarannya yang pada gilirannya berdampak positif bagi pengembangan Islam. Di antara kelompok-kelompok tersebut ada yang sangat berhasil melakukan proses "Islamisasi" khususnya secara internal meskipun yang disentuh biasanya terbatas pada aspek ritual dan moral. Segi negatif dari kelompok-kelompok ini adalah menyemarakkan kembali eksklusivitas di tubuh Islam yang mestinya sedapat mungkin dihindari dan menimbulkan kesan semakin terpecahnya umat Islam dalam sekte-sekte.

Perpecahan umat Islam ke dalam aliran-aliran yang berdampak pada renggangnya solidaritas dan ukhuwwah Islamiyyah merupakan masalah abadi yang dihadapi oleh umat Islam. Bahkan boleh dikatakan bahwa masalah ini bersifat universal untuk semua agama di dunia ini. Secara umum, khususnya di Indonesia, kemajemukan tersebut memiliki nilainilai positif dan negatif. Segi positifnya adalah terbukanya kesempatan untuk berkompetisi secara fair dalam beramal sālih, ber-amar ma’rū $f$ dan ber-nahi mungkar. Bahkan jalinan kerjasama antara kelompok Islam bisa mewujudkan kekuatan Islam yang dahsyat dan diperhitungkan. Kemajemukan itu juga menjadi bukti bahwa Islam adalah agama yang memiliki khazanah ajaran yang sangat kaya dan memberi peluang yang luas bagi umatnya untuk mengembangkan ajaran-ajaran agamanya sesuai dengan tuntutan reformasi perspektif Islam. Perbedaan-perbedaan di kalangan umat Islam adalah merupakan watak esensial dari agama yang di bawah Nabi Nabi Saw. Sisi negatifnya adalah terbukanya potensi disintegrasi di kalangan umat Islam karena gesekan-gesekan antar aliran dan kelompok seringkali tidak bisa dihindari. Gesekan-gesekan ini terkadang meningkat menjadi perseteruan tajam yang meretakkan hubungan antar umat Islam. Sisi positif dari kemajemukan ini mestinya lebih ditonjolkan agar umat Islam terbiasa dalam suasana perbedaan tanpa harus saling mengklaim, benar atau salah.

Dapat dirumuskan bahwa dalam pemetaan sejarahnya, perkembangan Islam diyakini akan lebih baik di era reformasi ini dibandingkan dengan era sebelumnya. Pada era reformasi ini organisasi-organisasi Islam semakin bertambah, dan partai-partai Islam dalam konteks kenegaraan diberi peluang yang sangat bebas menyampaikan aspirasinya. 


\section{Penutup}

Berdasarkan dari uraian sebelumnya, maka dapat disimpulkan bahwa pertumbuhan Islam di Indonesia, bermula pada abad ke-13 M di mana para pendakwah agama ( $d \bar{a}^{\prime} i$ atau $\left.m u b a l i g h\right)$ senantiasa giat menyebarkan agama Islam di tengah-tengah masyarakat, dan selanjutnya agama Islam mengalami perkembangan pada abad ke-17 $\mathrm{M}$ karena penyebaran agama ini mendapat dukungan dari raja-raja di berbagai wilayah nusantara. Di sisi lain, perkembangan Islam dapat dilihat dari banyaknya organisasiorganisasi Islam yang muncul, baik pada masa Orde Lama dan Orde Baru. Kemudian setelah memasuki era reformasi yang bermula pada 21 Mei 1997, agama Islam di negara ini semakin mengalami perkembangan yang signifikan. Pada era ini, bukan saja partai Islam semakin banyak, tetapi organisasi Islam semakin banyak pula, seperti Forum Pembela Islam (FPI), Majelis Mujahidin Indonesia (MMI), Laskar Jihad, Forum Komunikasi Ahli Sunnah Waljamaah (FKSW), Hizbut Tahrir.

Ciri khas lain perkembangan Islam di Indonesia di era reformasi, juga dibuktikan dengan jumlah penduduk Muslim yang semakin meningkat mencapai $+88 \%$. Hal ini karena kegiatan dakwah di era reformasi juga semakin meningkat dan mengalami perkembangan. Sesuai dengan kesimpulan di atas, maka implikasinya dan tak terelakkan menuntut pada setiap Muslim agar senantiasa terlibat dalam upaya pengembangan agama (Islam), baik dari segi perkembangan kuantitasnya dan kualitasnya. 


\section{Dafitar Pustaka}

Aminuddin. Kekuatan Islam dan Pergulatan Kekuasaan di Indonesia: Sebelum dan Sesudah Runtuhnya Soeharto. Yogyakarta: Pustaka Pelajar, 1999.

Al-Barry, M. Dahlan \& Pius A. Partanto. Kamus Ilmiah Populer. Surabaya: Arkola, 1994.

Boechari, Sidi Ibrahim. Pengaruh Timbal Balik antara Pendidikan Islam dan Pergerakan Nasional di Minangkabau. Jakarta: Gunung Tiga, 1981.

al-Hakim, Abd. al-Hamid. al-Bayān fī Ilm al-Ushul. t.t.: Maktabah Dahlān, 1978.

Hasbullah. Sejarah Pendidikan Islam di Indonesia. Cet. IV. Jakarta: PT. Raja Grafindo Persada, 2001.

Lapidus, Ira M. A History of Islamic Societies (Sejarah Sosial Umat Islam), terj. Ghufran A. Mas'adi. "Bagian Kesatu dan Dua." Cet. III. Jakarta: PT. Raja Grafindo Persada, 2003.

Prasetyo, Eko. Membela Agama Tuhan: Potret Gerakan Islam Pusaran Konflik Global. Cet. II. Yogyakarta: IPPI, 2003.

Samiun, Suwardi Muhammad, et.al. Peranan Kerajaaan Siak dalam Sejarah Nasional Indonesia. Pekan Baru: Universitas Riau, 1970.

Sewang, Ahmad. Islamisasi Kerajaan Gowa. Cet. II. Jakarta: Yayasan Obor Indonesia, 2005.

Syamsu AS, Muhammad. Ulama Pembawa Islam di Indonesia dan Sekitarnya. Jakarta: Lentera Basritama, 1999.

Thohir, Ajid. Perkembangan Peradaban di Kawasan Dunia Islam. Jakarta: PT. Raja Grafindo Persada, 2004.

Zuhairini, et.al. Sejarah Pendidikan Islam, Cet. II. Jakarta: Proyek Prasarana dan Sarana Perguruan Tinggi Agama, Dirjen Pembinaan Kelembagaan Agama Islam, 1986. 